\section{Mitral Valve Disease}

A symposium on advances in diagnosis and treatment of mitral valve disease was held at a regular meeting of the Section of Biological and Medical Sciences at the New York Academy of Sciences on October 14, 1963 (Ann. N.Y. Acad. Sci., 118, Article 10: Mitral Valve Disease, by J. D. Baker and 11 other authors. Pp. 469 536. New York: New York Academy of Sciences, 1965). The moderator was G. H. Humphreys, who summed up the symposium as follows: "Disease of the mitral valve, usually of rheumatic but occasionally congonital origin, continues to be a major cause of disability in human beings in most countries of the world. It is interesting that the same valve is a frequent cause of heart failure in dogs, though the etiology appears to be different. It is of importance, therefore, that the search for better understanding of the pathological physiology, and improved diagnostic methods often based on, and sometimes adding to, this understanding be continuously pursued. At the same time, methods of more effective surgical correction of the valve are now available, so the criteria for selection of pationts and choice of proceduro must constantly be refined. It is evident from the papers presented in the symposium that much remains to be done in this field. If the experience in animal hospitals can be correlated with that in human, it is possible that new avenues of investigation may be opened".

\section{The Association of Clinical Biochemists}

THE following have boen elected officers of the Associa. tion of Clinical Biochemists for 1965-66: President, Prof. R. H. S. Thompson (Courtauld Institute of Biochemistry, London); Chairman, Dr. R. Gaddie (General Hospital, Birmingham); Secretary, Dr. A. H. Gowenlock (Chemical Pathology Department, University of Manchester); Treasurer, Dr. D. B. Horn (Royal Victoria Infirmary, Newcastle upon Tyne).

\section{Bullard Forest Research Fellowships}

Appratcations are invited for research fellowships in forest resources which are awarded annually by Harvard University from the Charles Bullard Fund. Such fellow. ships are tenable for one year and carry stipends up to 15,000 dollars. They are open to men in public service, in academic careers and in private forestry, with or without advanced degrees, who show promise of important contributions to forestry, which study and research at Harvard University will help to fulfil. Further information can be obtained from the Committee on the Charles Bullard Fund for Forest Research, Littauer Center 119 , Harvard University, Cambridge, Massachusetts.

\section{Guinness Awards for Science and Mathematics Teachers}

The Guinness Awards for Science and Mathematics Teachers are now to be extended so as to include Africa. This extension follows experience of the first results in the Guinness Awards programme in Ghana during 1964. The Awards scheme will now include the whole of Englishspeaking Africa. It is to bo carried out in association with the Afro-Anglo-American conference financed by the Carnegio Corporation. Money prizes totalling $£ 350$ and certificates will be awarded. The purpose is to encourage teachers in schools and colleges in Africa to develop and report on the teaching of science in Africa with special reference to adaptations related to the African environment. The scheme for Africa will go into operation immediately and the first Awards are expected to be announced in April 1967.

The Guinness Awards for Science and Mathematics Teachers are also to be extended so as to include all schools run overseas by the Armed Forces. The three Services have agreed to collaborate, and the Royal Air Force
Educational Organization is to act as the co-ordinating centre. The first Awards will be anmounced in April 1967. Also to encourage mathematics, it has been agreed that financial and administrative aid shall be provided for the following two schemes: first, a National Mathematics Contest, now in its third year, in which the entrants are students in secondary schools, mainly grammar and public schools (in 1965 there were 5,000 entrants from 109 schools in the United Kingdom for this contest); scondly, the Mathomatics Olympiad, organized by Prof. $W$. K. Hayman, of the Dopartment of Mathematics, Imperial College of Science and Technology, and Mrs. Hayman, a mathematics teacher at Mayfield School, Londor. This scheme began in 1965. The first Awards under the auspices of the Guinness Awards for the National Mathematics Contest and for the Mathematics Olympiad are to be made in April 1966. As a result of the extensions to the Guinness Awards outlined here, the total value of prize money to be awarded annually will now be $£ 1,500$. Further information can be obtained from $\mathrm{Mr}$. Maurice Goldsmith, c/o The Science Teacher, 60 Paddington Street, London, W.I.

\section{Announcements}

Mr. W. T. Cooper, research editor of the Division of Coal Research, Commonwealth Scientific and Industrial Research Organization, has been appointed to succeed Prof. N. Y. Kirov as chairman of the Institute of Fuel (Australian Membership).

A Menting of the Welsh Soils Discussion Group on "The Fauna and Flora of the Soil" will be held in the University College of North Wales, Bangor, on November 24. Further information can be obtained from C. C. Rudeforth, Soil Survey, Trawscoed, near Aberystwyth, Cardiganshire.

AN ordinary meeting of the Scottish Section of the Society for Analytical Chemistry will be held in the University of Strathclyde on November 26. A paper on "Separate or Calculate" will be presented by Dr. A. L. Glenn. Further information can be obtained from the Society for Analytical Chemistry, 14 Belgravo Square, London, S.W.I.

A LECTURE on "The Reliability of Electronic Systems" will be delivered by Dr. Irving Bosinoff (Mitre Corporation, Bedford, Massachusetts) at the Institution of Electrical Engineers on December 3. Further information can be obtained from Dr. G. S. Brayshaw, Northampton College of Advanced Technology, St. John Street, London, E.C.1.

A JoINT meeting of the Scottish Section of the Society for Analytical Chemistry and the local sections of the Chemical Society, the Royal Institute of Chemistry and the Society of Chemical Industry will be held in the University of Strathclyde on December 3. A paper on "Chemistry for Profit" will be presented by Dr. J. W. Barrett. Further information can be obtained from the Society for Analytical Chemistry, 14 Belgrave Square, London, S.W.1.

THE 1966 Gordon Research Conferences will bo held in Santa Barbara, California, during January 24 February 4. The purpose of the Conferences is to stimulate rosearch in universities, research foundations and industrial laboratories and is achieved by an informal type of meeting consisting of scheduled lectures and discussion groups. The programme will include conferences on: polymers (January 24-28); chemistry of ageing (January 24-28); electrochemistry (January 31-February 4); formulation of research policies (January 31-February 4). Further information can be obtained from W. George Parks, Department of Chemistry, University of Rhode Island, Kingston, Rhode Island. 